\title{
8. Agency and Salvation in Christian Child Rescue in Colonial India: Preena and Amy Carmichael
}

\author{
Annie McCarthy \\ The Australian National University
}

\section{Introduction}

On 6 March 1901, a young girl insistently requesting "the child-stealingAmmal" (mother) is brought before Miss Amy Carmichael, ${ }^{1}$ a Keswick missionary with the Church of England Zenana Missionary Society (CEZMS) in the South Indian district of Tinnevelly (Tirunelveli). ${ }^{2}$ Unafraid, the young girl quickly declared, "My name is Pearl-eyes ... and I want to stay here always. I have come to stay." ${ }^{3}$ Despite the actual circumstances of Pearl-eyes' (Preena's) arrival, ${ }^{4}$ she is consistently described as Miss Carmichael's first rescued child, marking the beginning of her life-long fight for "little [temple] girls, who can never fight for themselves!"5 The absurdity of this statement in light of Preena's obvious efforts is one disregarded by both supporters and critics of Carmichael's work, who insist on seeing only the blessing or violence in her project to "rescue children from temple danger." ${ }^{16}$ Drawing primarily from three of Carmichael's most famous

\footnotetext{
1 Amy Carmichael appended the additional surname Wilson to her name on request of her adopted father Robert Wilson when submitting her initial application to serve as a missionary. Despite Wilson's death in 1905 she continued to use the hyphenated surname Wilson-Carmichael until 1912. I will refer to her throughout this paper as Amy Carmichael. Her works cited in this paper will retain the version of her name as published. 2 Amy Wilson-Carmichael, Things as They Are: Mission Work in Southern India, London: Morgan \& Scott, 1903, p. 166. I was lucky enough to stumble across a copy of Amy Wilson-Carmichael's Things as they Are: Mission Work in Southern India in the university library at The Australian National University. I was able to access Carmichael's other texts though online digitised text archives such as Project Gutenberg and the Internet Archive. Similarly texts such as India's Women: The Magazine of the Church of England Zenana Missionary Society, as well as colonial documents such as Indian Educational Policy, 1913 were accessed via Internet Archive, http://archive.org/.

3 Ibid., p. 161.

4 I have decided throughout my telling to use the name Preena as it the one used consistently in later publications. To retain the tone of Amy Carmichael's voice I will however render all quotes faithfully. As such the reader may expect to encounter Preena, under the additional names of Pearleyes or The Elf.

5 Wilson-Carmichael, Things as They Are, p. 234.

6 Alongside this successful escape Carmichael describes another, more arduous attempt made by Preena to return home to her recently widowed mother. Having escaped from the temple, Preena set out for her home town of Tuticorin two days journey by cart distant. Receiving help from passing cartiers she eventually arrives at her mother's house. Having been followed by temple women, who threatened her mother, she was once again forced to return to the temple. On her return Preena overheard plans for her imminent marriage to the God. Again she decides to escape. This time hearing fellow temple-women describe a passing missionary
} 
works, Things as They Are: Mission Work in Southern India (1903), Lotus Buds (1909) and Gold Cord: The Story of a Fellowship (1932), this chapter will paint a more nuanced picture of one girl's "rescue," "conversion," and "maturation."7

Before we begin "reading" Carmichael's texts it is worth considering the distances that inform my re-configuration of this textual and photographic material. Reading this and Carmichael's other works in a contemporary secular milieu, in which the boundaries of truth and prejudice have been dramatically re-drawn, Carmichael's arch confidence, unwavering convictions and recklessly catastrophic "rescue" attempts can be "extremely unsettling, even upsetting." Yet, while acknowledging these legitimate reactions, a contextualised reading of these texts must acknowledge a resistance that plays out both within these texts and in circumstances external to them. Even within blatantly hagiographical texts such as Elizabeth Elliot's biography of Carmichael, a sense of resistance remains evident. ${ }^{9}$ Elliot writes, "There arose during the early years of the Dohnavur work a fairly strong, "Get-Amy-Carmichael-out-of-India" movement among missionaries and Indian Christians." ${ }^{10}$ Similarly a cross reading of Carmichael's own writing suggests an element of resistance yet to be acknowledged in postcolonial readings that see only the violence of "child rescue." In highlighting aspects of Preena's story that suggest resistance and agency I, following Jane Haggis, remain mindful of the undesirability of a frame in which "the colonized continue to be caught in the colonizer's gaze, now also overlaid with the contemporary reflection of First/Third World dissonance."11 Similarly, I consider my choice of Preena's narrative indicative not of an egotistic predilection for "so-called rabble-rousers and gender trouble makers" that for Chad M. Bauman amounts to a "too-limited conception of human agency."12 Rather, in charting

as a "child-stealing Ammal," Preena formulates her second plan. See Amy Carmichael, Gold Cord: The Story of a Fellowship, London: Society for Promoting Christian Knowledge, 1932, pp. 20-23 and Wilson-Carmichael, Things as They Are, pp. 161-68.

7 Carmichael's most famous works are, Things as They Are: Mission Work in Southern India, London: Morgan \& Scott, 1903; Lotus Buds, London: Morgan \& Scott, 1909; and Promoting Christian Knowledge, 1932. To fill out Preena's trajectory I will also draw on Overweights of Joy, New York: Fleming H. Revell Company, 1906, and The Continuation of a Story, London: Dohnavur Fellowship, 1914.

8 Jo-Ann Wallace, "Lotus Buds: Amy Wilson-Carmichael and the nautch-girls of south India," Victorian Review 24(2) (1998): pp. 175-93, p. 175. Here I quote Jo-Ann Wallace's reaction to Carmichael's 1909 book, Lotus Buds, of which she writes "I found the book extremely unsettling, even upsetting: its fifty photo illustrations, almost all of them highly aestheticised potraits of children, and its highly sentimentalised rhetoric of childhood (in which girls are invariably described as 'buds' and boys as 'teddies') seemed at odds both with its descriptions of the 'evils' of the Hindu 'temple system' and its narrative describing the virtual kidnapping of Hindu infant girls, many of whom, in the absence of a wet nurse, did not survive the 'rescue."' See Wallace, "Lotus buds," p. 175.

9 Elizabeth Elliot, A Chance to Die: The Life and Legacy of Amy Carmichael, Grand Rapids: Revell, 2005.

10 Ibid., quoted in Dyron Daughrity, Bishop Stephen Neil: from Edinburgh to South India, New York: Peter Lang, 2008, p. 100.

11 Jane Haggis, "'Good wives and mothers' or 'dedicated workers'? Contradictions of domesticity in the 'mission of sisterhood,' Travancore, South India," in Maternities and Modernities: Colonial and Postcolonial Experiences in Asia and the Pacific, ed. Kalpana Ram and Margaret Jolly, Cambridge: Cambridge University Press, 1998, pp. 81-113, p. 83.

12 Chad M. Bauman, “Redeeming Indian 'Christian' womanhood? Missionaries, Dalits and agency in colonial India," Journal of Feminist Studies in Religion 24(2) (2008): 5-27, p. 8. 
the shifting spheres of agency through the domains of rescue, conversion and maturation, my reading of Preena's life attempts to contextualise and expand the conceived scope of child and youth agency in the colonial mission field. Additionally, it is worth reflecting on the value of a reading of "Preena's life" that re-casts her at the centre of a narrative in which she has too long remained ancillary to Carmichael.

\section{Capturing “lively originals"}

Amy Carmichael, reflecting on the act of writing would suggest, "Words should be like colours, each one a dot of colour supplying a need, not one over." 13 Her emotive prose, while in her mind "moderate," paints starkly black and white pictures of a mission field plagued and continually undermined by the horrors of Hinduism. Perhaps mindful of the broader colonial concerns that "to represent India by mere word-painting is almost an impossible task," ${ }^{14}$ she complemented her writings with numerous photographs. Describing the process of "catching" pictures for her early book Things as They Are Carmichael writes of her friend the "picture-catching Missie Ammal," so called for how "she struck the Tamil mind."

The pictures she caught were not so easy to catch. Reserved and conservative India considered the camera intrusive, and we were often foiled in getting what we most desired. Even where we were allowed to catch our object peaceably, it was a case of working under difficulties which would have daunted a less ardent picture catcher. ${ }^{15}$

This description has some interesting resonances with the words of Samual Bourne's Narrative of a Photographic Trip to Kashmir (Cashmere) and Adjacent Districts published in The British Journal of Photography in $1863 .{ }^{16}$

From the earliest days of the calotype, the curious tripod with its mysterious chamber and mouth of brass taught the natives of this country that their conquerors were the inventors of other instruments beside the formidable guns of their artillery, which, though as suspicious perhaps in appearance, attained their objects with less noise and smoke. ${ }^{17}$

\footnotetext{
13 Frank Houghton, Amy Carmichael of Dohnavur: The Story of a Lover and her Beloved, London: Society for the Promotion of Christian Knowledge, 1953, p. 333.

14 John William Kaye, "Preface," in William Simpson, India Ancient and Modern: A Series of Illustrations of the Country and the People of India and Adjacent Territories; Executed in Chromo-lithography from Drawings by William Simpson; with Descriptive Literature by John William Kaye, London: Day and Son, 1867, p. 1, quoted in Christopher Pinney, Camera Indica: The Social Life of Indian Photographs, Chicago: the University of Chicago Press, 1997, p. 17.

15 Wilson-Carmichael, Things as They Are, pp. 2-3.

16 Samuel Bourne, "Narrative of a photographic trip to Kashmir (Cashmere) and adjacent districts," The British Journal of Photography xiii(335) (1866-1867), quoted in Pinney, Camera Indica, p. 75.

17 Ibid.
} 


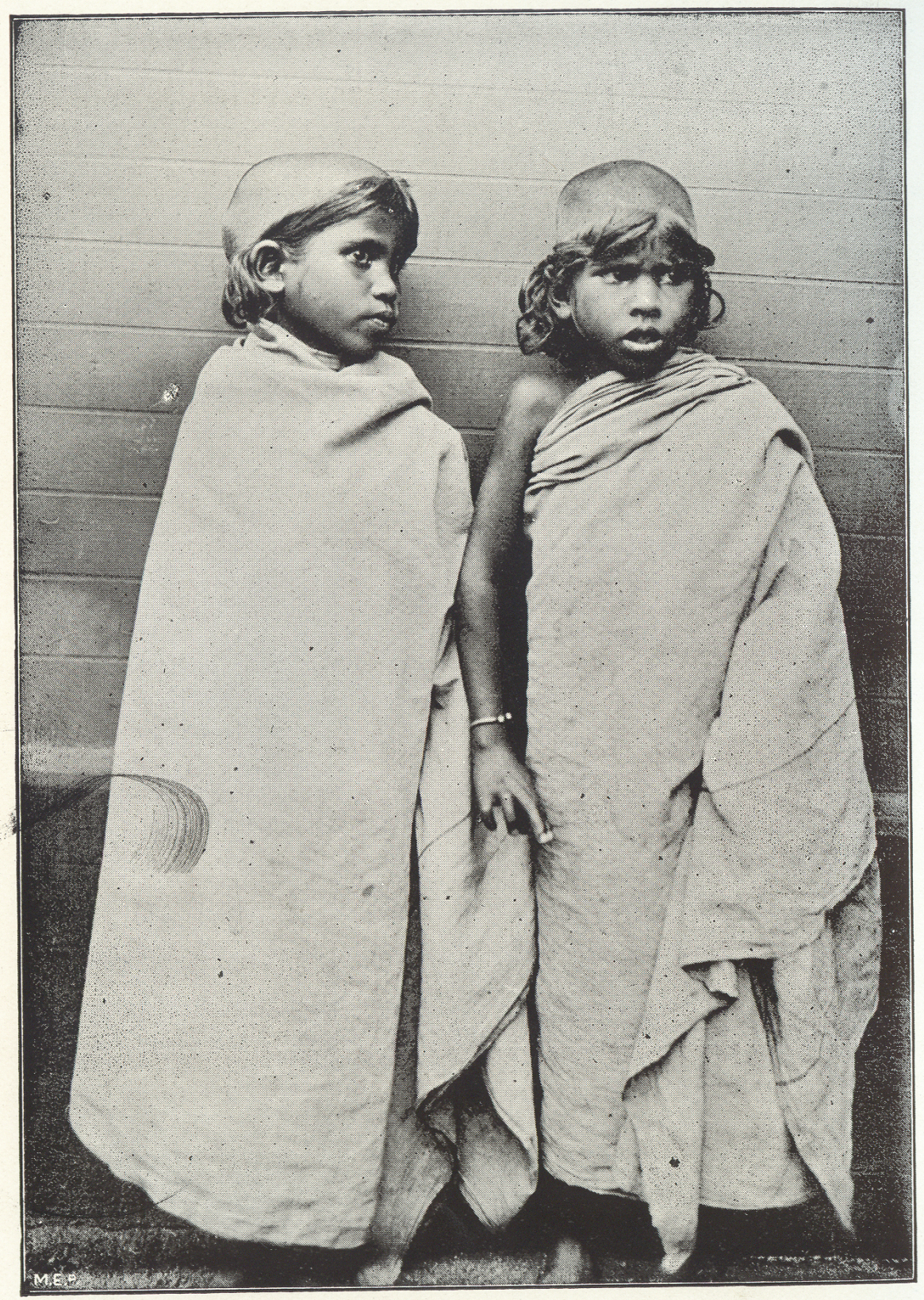

BADAGA GIRI,S.

\section{Figure 21. Badaga Girls}

Source: Photographer Mr. Penn, in Edgar Thurston, Castes and Tribes of Southern India, vol. 1, Madras: Government Press, 1909, p. 76. 


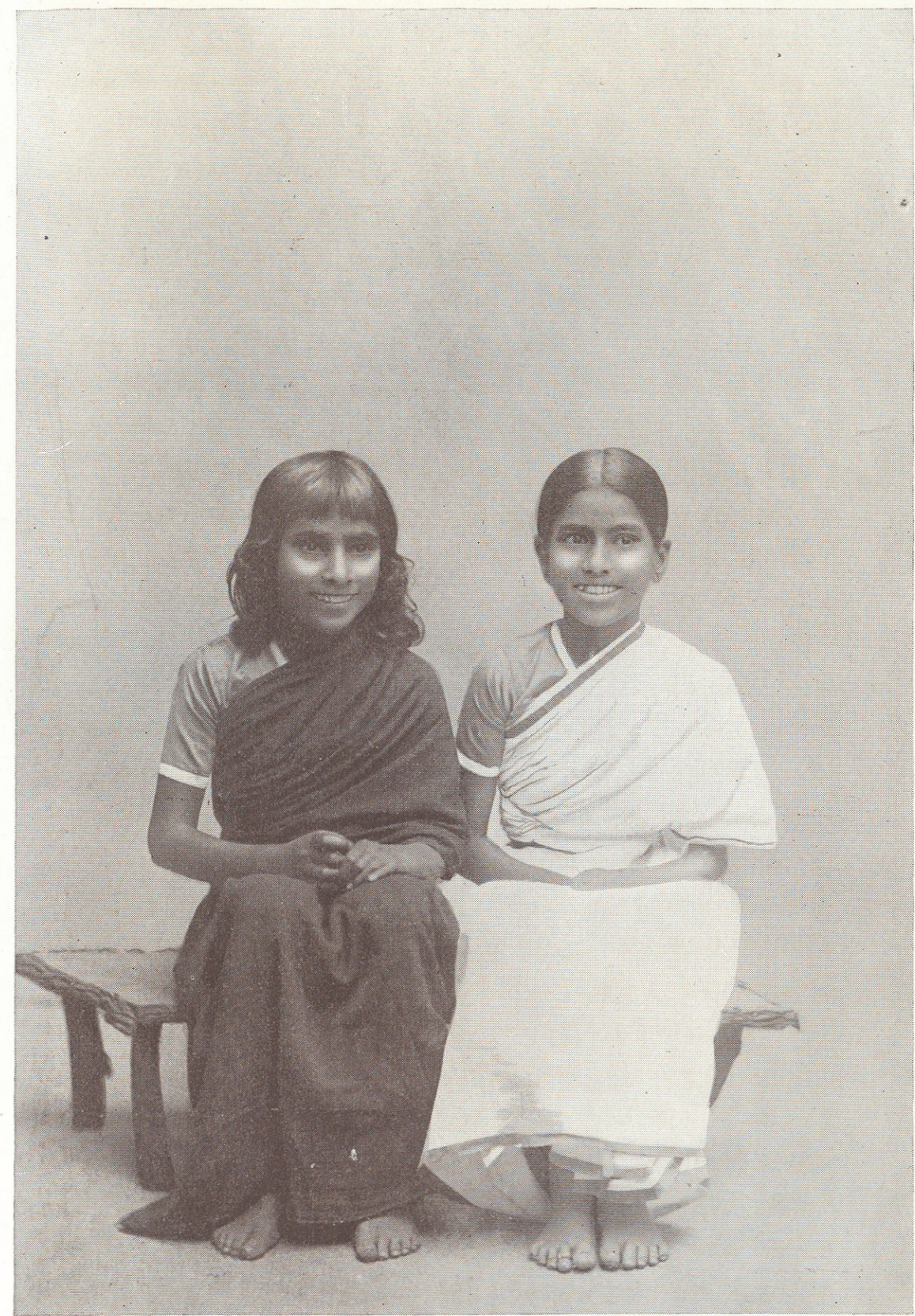

Preena and Lavana-the Elf and the Flower-a year later.

\section{Figure 22. Preena and Lavana, "The Elf and the Flower"}

Source: Unknown photographer, in Amy Carmichael, Overweights of Joy, London: Morgan \& Scott, 1906, p. 254. 


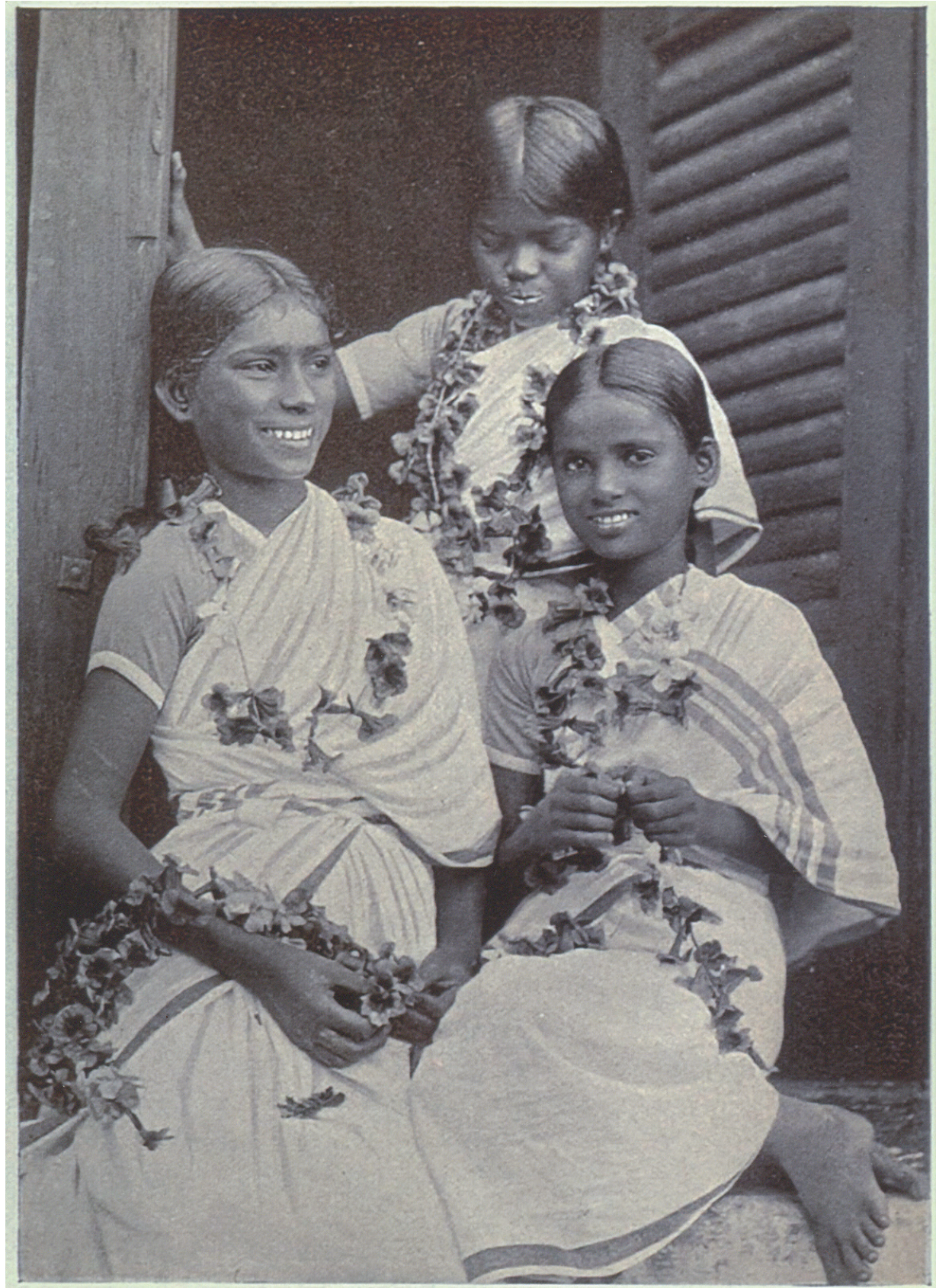

Figure 23. Preena and Preeya getting ready for a coming feast day

Source: Photographer Mr. Penn, in Amy Carmichael, Lotus Buds, London: Morgan \& Scott, 1909, p. 231. 
In analysing both the pictures of Preena and those that surround her story, the resonances with ethnographic photography cannot be ignored. Of particular note is the picture included alongside the first iteration of Preena's story in Things as They Are. Rather than a picture of Preena, the caption admits, "This is not Pearl eyes [sic]. Pearl-eyes is tinier, and has more sparkle; but the Caste is the same; and as we have not got Pearl-eyes, we put this small girl here." ${ }^{18}$ While the cause for Preena's photographic absence is not suggested, her easy substitution suggests an ethnographic lens capturing not individuals but "anonymous 'typical' representatives of particular categories": An "indexicality" in which "individual faces were largely displaced by generic masks rendered visible to the state." ${ }^{19}$ Yet despite utilising the photographic services of Mr. Penn, known for his contributions to Edgar Thurston's seven-volume ethnographic profile Castes and Tribes of Southern India (1909) (see Figure 21), ${ }^{20}$ Carmichael's later books contain more personalised, portrait style pictures of her "family" (see Figures 22 and 23). Described by Miss Carmichael as "more accustomed to the dignified ways of mountains than to the extremely restless habits of children," Mr. Penn, visiting in 1908, took a series of photographs, fifty of which featured in Carmichael's book Lotus Buds as photogravure illustrations. ${ }^{21}$

These, Carmichael describes as "insipid as compared with their lively originals" suggesting that "an Oriental scene in print always looks sorry for itself, and quite apologetic. It knows it is almost a farce, and very flat and poor." ${ }^{22}$ Carmichael's lament seems to betray a desire to move beyond illustrative shots to what in Lotus Buds resembles a family album. Jo-Ann Wallace noting that "All three editions are expensively bound and lavishly illustrated with professional photographs of very young Indian girls," suggests Lotus Buds is "clearly intended as a giftbook." ${ }^{23}$ In contrast to this, Carmichael's images and descriptions of people and places outside of her compound retain a crudely focused ethnographic lens: essentialist, dismissive and overly damming. Let us consider her description of the Temple from which Preena escaped, which Miss Carmichael was, thirty years later, able to capture with emotive words and pictures (Figures 24 and 25):

It is not like our towered temples of further South. An immense wall surrounds it; but what can be seen from adjacent roofs, it appears a squat structure or conglomeration of structures clustered together, and reminds one of nothing so much as the monstrous Indian spider which hangs its web from branch to branch of forest trees, and lies in wait in

18 Wilson-Carmichael, Things as They Are, p. 162.

19 Pinney, Camera Indica, pp. 23, 97.

20 Edgar Thurston, Castes and Tribes of Southern India, vol. 1, Madras: Government Press, 1909.

21 Wilson-Carmichael, Lotus Buds.

22 Ibid., p. 26.

23 Wallace, "Lotus buds," p. 178. 
the middle. The web is strong enough to hold little birds and butterflies which are often bigger than little birds. From such webs our children are disentangled, bright birds and butterflies indeed. ${ }^{24}$
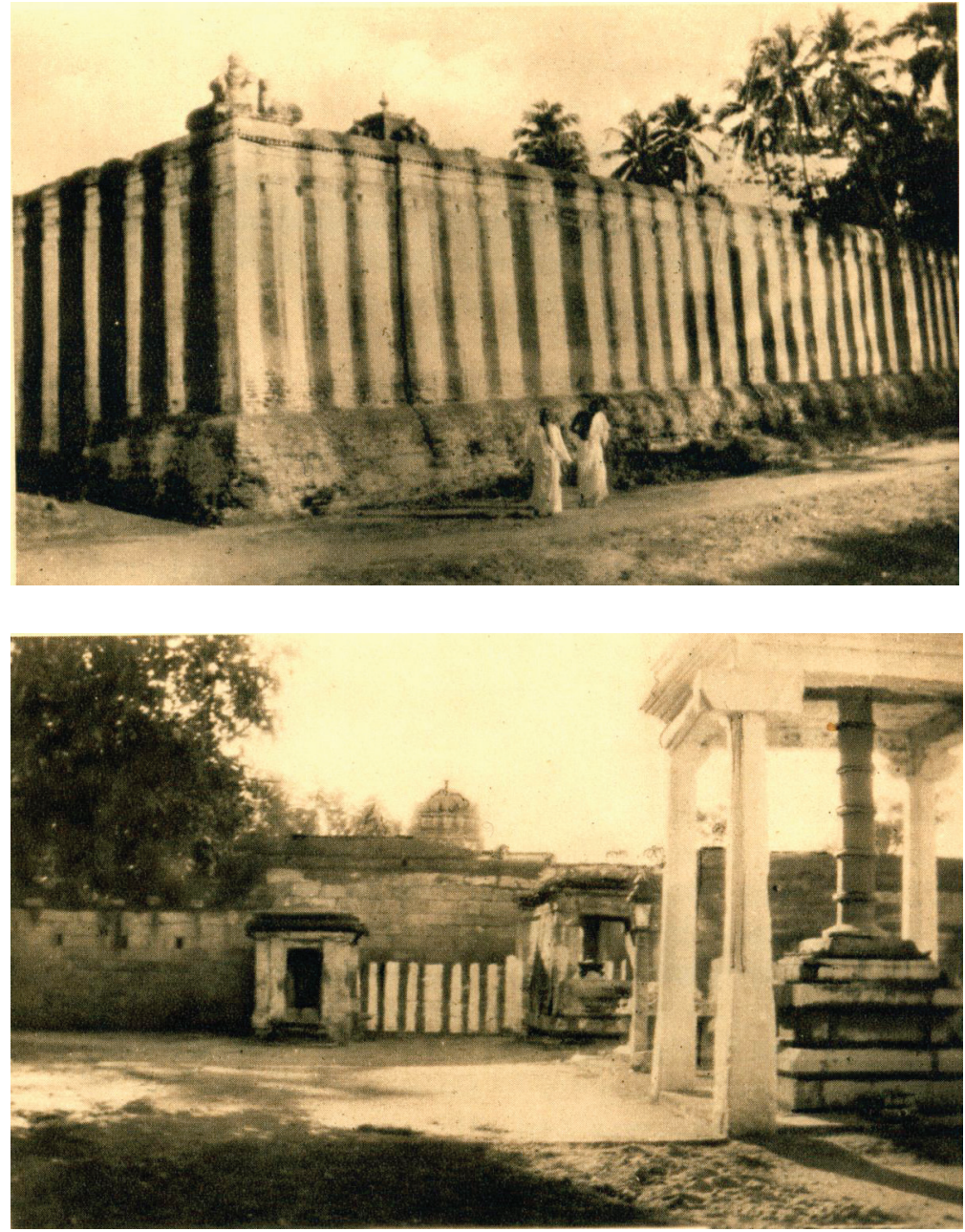

Figures 24 and 25. The Temple

Source: In Amy Carmichael, Gold Cord: The Story of a Fellowship, London: Society for Promoting Christian Knowledge, 1932, p. 21, unknown photographer.

24 Despite this emotive language, an interesting footnote to this section reminds the reader of both the role of Indians in ending "the wrongs that still persist" and the problematic nature of throwing stones whilst inhabiting glass houses: "Nothing written here or elsewhere in this book or in any Dohnavur book is told in forgetfulness of the sins of the West." See Carmichael, Gold Cord, p. 20. 


\section{Rescue}

The webs in Carmichael's fantastical metaphor stand for the adoption practices of the "slaves of the gods." ${ }^{25}$ Carmichael here, using a direct translation of the Tamil Tevaradiiyals (Slaves of the God), refers to women who more broadly were known as devadasis. These women who were often dedicated to the temple as young girls were trained in performance arts and married to a temple deity through a series of ceremonies, the last of which, taking place after puberty cemented their status as "nityasumangali ... one who is free from widowhood." 26 From then onwards, the devadasi would perform services in the temple, participate in village life-cycle rituals and were "free to choose her patron who could also act as her sexual partner without having to marry her." 27 These patronage arrangements often involved land or other financial exchanges over which the devadasi retained an inheritance right only so long as she could provide a female heir as her successor in the temple. ${ }^{28}$ This practice described elsewhere by Amy Carmichael as "a great secret traffic in souls and bodies of young children," ${ }^{29}$ was in 1877, eighteen years prior to Carmichael's arrival in India, included in Whitley Stoke's explanation of the successes of the Indian Penal code of 1862:

Besides repressing the crimes common to all countries, it has abated, if not extirpated, the crimes peculiar to India, such as thuggee, professional sodomy, dedicating girls to a life of temple-harlotry, human sacrifices, exposing infants, burning widows, burying lepers alive, gang-robbery, torturing peasants and witnesses, sitting dharof. ${ }^{30}$

The premature nature of this declaration is noted by Parker who suggests "the legislative history of these provisions reveals no intention on the part of the framers of the Indian Penal Code of targeting temple dancing girls. The crime of "dedicating girls to a life of temple-harlotry" was, therefore, a pure judicial invention." ${ }^{31}$ This invention required the representation of devadasis as "prostitues," "not as participants in a sex trade but in terms of Hindu legal norms according to which all female sexual activity outside marriage was designated 'unchastity', 'incontinence' or 'prostitution'." 32 As Phillippa Levine explains,

\footnotetext{
25 Wilson-Carmichael, Things As They Are, p. 192.

26 S. Anandhi, “Representing Devadasis: 'Dasigal Mosavalai' as a radical text," Economic and Political Weekly 26(11-12) (1991): 739-46, p. 739.

27 Ibid.

28 Ibid., p. 740.

29 Carmichael, Gold Cord, p. 22.

30 Whitley Stoke (ed.), The Anglo-Indian Codes. Vol 1., Oxford: Clarendon Press, 1887, p. 71.

31 Kunal M. Parker, “A corporation of superior prostitutes' Anglo-Indian legal conceptions of temple dancing girls, 1800-1913," Modern Asian Studies 32(3) (199): 559-633, p. 562.

32 Parker, "'A corporation of superior prostitutes,"” pp. 562-63.
} 
"For the British, the devadasi was not the servant and wife of the gods, but a slave to unharnessed human desire and a profound threat to Victorian readings of the marriage contract." ${ }^{33}$

Carmichael was by her own account virtually ignorant of this custom before Preena's arrival, after which she dedicated her life to "rescuing" "children in temple danger" or those who "could not have grown up good if we had not taken them" — a mission made most explicit in her 1909 book Lotus Buds. "The little Lotus buds are His-His and not another's. The children of the temple of South India are His - His and not another's. So now we go forth with the Owner himself to claim His own possessions." ${ }^{\prime 34}$

While Carmichael's books are filled with tales of "rescued" children, many of whom are bought or secretly smuggled into missionary care, ${ }^{35}$ others give glimpses into the other side of these "rescue attempts." Carmichael recounts how, on returning several years later to Preena's village, "the women interfered, and whispered to the children about our having come to catch them by magic, as we had caught the Elf." ${ }^{36}$ Speaking of another village she tells of "a story about magic which, say what we will, they imagine I dust upon children's faces." ${ }^{37}$ Most evocative of these is Carmichael's account of Rungi who happily tells the missionaries that she is going to be a servant of the gods: "The child's hands were in ours, her brown eyes fixed on us filled us with surprise, then compassion. 'Tears?' she exclaimed. 'Tears?' Oh, Why? Am I not going to be just what you are? Are you not also servants of the Gods?"38 Rungi's confusion is a provocative and striking example of the dialogic encounters between Miss Carmichael and the objects of her "rescue" attempts. Just as Preena seems to have regarded her fortunes with the "Child-stealing Ammal" to be better than those in the temple, a quick look at an alternative trajectory forged by another devadasi of this period enables us to further contextualise these "rescue" attempts.

Moovalur Ramamirtham Ammaiyar was born in 1883 into the same caste as Preena. From a very young age she was initiated and brought up in the "dasi"

33 Phillippa Levine, "A multitude of unchaste women': prostitution in the British Empire," Women's History 15(4) (2004): 159-63, p. 161.

34 Wilson-Carmichael, Lotus Buds, p. 4.

35 By no doubt the most arresting of these is the story of Jewel. Jewel's family, displeased with the removal of their daughter from the temple tried on numerous occasions to have Miss Carmichael prosecuted in court and their daughter returned to the temple. Finally successful, Carmichael rather than returning Jewel describes the events that followed: "the court of heaven intervened." Jewel was passed from hand to hand until a missionary smuggled her out of India to China where she remained in missionary care for six years before returning to Dohnavur and Amy Carmichael's mission where she married a fellow worker and raised her children in the mission, one of whom came to be one of the leading Indian members of the leadership team at the time of Amy's death. See Carmichael, Gold Cord, pp. 99 and 231.

36 Amy Wilson-Carmichael, Overweights of Joy, New York: Fleming H. Revell Company, 1906, p. 243.

37 Wilson-Carmichael, Things As They Are, p. 219.

38 Carmichael, Gold Cord, p. 174. 
system. ${ }^{39}$ In 1925 writing in Kudi Arasu (the official organ of the Self-Respect Movement) she recalled, "My parents forced me into this custom. It was during this time, I deeply thought about this custom as evil and read those religious texts which advocated it. I felt that men have forced certain women into this degrading profession to pursue their indiscreet pleasures for selfish reasons." ${ }^{40}$ Sure of her convictions she left her devadasi life, marrying her music teacher. Ostracised from her community, she continued her political activism, first with the Congress party and later in the Self-Respect Movement where she worked to encourage devadasis to break from the system, both through political movements but also individually "through marriages with someone of their own choice." ${ }^{41}$ Ramamirtham's courageous story provides a useful frame for the consideration of Preena's own exceptional story: suggesting subtly that the seemingly exceptional character of these two stories might derive from the dominant "discourse of rescue" rather than the actual exceptionality of individual self-assertion and agency. Re-thinking "rescue" in the context of Amy Carmichael's work, we must also consider the way in which a dominant discourse of "rescue" acts as a filter both limiting the scope of surviving material but casting its shadow upon the stories that remain.

\section{Conversion}

In 1930 a bill was introduced into the Madras Legislative Council to prevent the "dedication of women to Hindu temples in the Presidency of Madras." ${ }^{42}$ While the bill did not become law until after 1947 these legal incursions into her domain were dismissed by Miss Carmichael:

But what of the law? They will do as they choose ... we are thankful that some are working for a better law. It is a move in the right direction, but we put not our trust in princes or any powers of this present age. The coming of the Lord of Righteousness is the one hope, as we see it, for this land. ${ }^{43}$

Rescue from the temple was, for Carmichael, only one aspect of the greater mission of rescuing souls for Jesus; a process she understood as contextualised and embodied. Miss Carmichael scoffed at the request of a donor that his contributions be spent only on the winning of souls. Similarly, "To critics who accused her of focusing too much on humanitarian activities, she responded,

\footnotetext{
39 Anandhi, “Representing Devadasis," p. 741

40 Ibid.

41 Ibid.

42 Ibid., p. 740.

43 Carmichael, Gold Cord, pp. 253-54.
} 
'One cannot save and then pitchfork souls into heaven.... Souls are more or less securely fastened to bodies."'44 Before I turn to a discussion of the particularities of Preena's conversion experience I will briefly provide some background into the experience of conversion and Christianisation in the area, as well as the theological and contextual specifics of Carmichael's place within this mission field.

From the initial Christian incursions into the southern Indian district of Tinnevelly and the neighbouring princely state of Travancore mass conversions of lowcaste groups contributed to a rapidly growing nominal Christian population. These, alongside the rapidly changing circumstances of colonial capitalism, pre-existing caste tensions and shifting Hindu religio-political norms, created a preponderance of land disputes and caste struggles in this region during the nineteenth and early twentieth centuries. Christian missionaries and converts were implicitly bound up in these struggles for basic rights as well as disputes over the more symbolic aspects of caste status. ${ }^{45} \mathrm{~A}$ visiting missionary travelling in Tinnevelly in 1885 would describe the region as the field of "some of the most successful missionary enterprises the world has ever seen." 46 By 1880 the CEZMS would record in its magazine five lady missionaries assisted by twenty Bible women and fourteen native helpers for the regions of Tinnevelly, North Tinnevelly and Palamcottah. ${ }^{47}$ This number would continue to increase - the publication in 1893 recording five missions in home connection with fortytwo Bible women operating in the Tinnevelly district. Similarly in Tinnevelly and Palamcottah the CEZMS were able to boast of entry to seven hundred and six houses and eight hundred and twenty-two pupils. ${ }^{48}$ Raging against these "wonderful sums" Amy Carmichael would write, "According to the present rate of advance, it will be more than twenty thousand years before the Hindu towns of this district are even nominally Christian." ${ }^{49}$ This nominally Christian population drew much criticism from Carmichael,

Was it that the power to understand had been withered up within them? Was the soul God gave them dead-"sentenced to death by disuse"?

\footnotetext{
44 Ruth Tucker, From Jerusalem to Irian Jaya: A Biographical History of Christian Missions, Michigan: Zondervan 2004, p. 300.

45 Of particular relevenace is the Shanar/Nadar community. See Hugald Grafe, History of Christianity in India: Volume IV, Part 2, Tamilnadu in the Nineteenth and Twentieth Centuries," Bangalore: Church History Association of India (CHAI), 1990; Robert L. Hardgrave, Jr., “The breast-cloth controversy: caste consciousness and social change in Travancore," Indian Economic Social History Review 5 (1968): 171-87; Eliza F. Kent, Converting Women: Gender and Protestant Christianity in Colonial South India, Oxford and New York: Oxford Univesity Press, 2004.

46 Murray Mitchell, In Southern India: A Visit to some of the Chief Mission Stations in the Madras Presidency, London: Religious Tract Society, 1885, p. 152.

47 India's Women: The Magazine of the Church of England Zenana Missionary Society, London: James Nisbet \& Co., 1886, pp. vi-vii.

48 Ibid.

49 Wilson-Carmichael, Things As They Are, p. 106.
} 
Dead they are in apathy and ignorance and putrefying customs, and the false security that comes from adherence to the Christian creed without vital connection with Christ. These poor Christians are dead..$^{50}$

The vehemence of this quote suggests the unique influences on Carmichael's Christianity. Most significant amongst these was her exposure to the "conservative evangelicalism" ${ }^{151}$ of the Higher Life Movement through Keswick conventions. After an unsuccessful missionary posting in Japan, Miss Carmichael, a 28-yearold single missionary lady of Northern Irish origin arrived in India in 1895. From her "itinerating" 52 work in Tinnevelly, she was ultimately lured to Dohnavur in 1900 by the "fiery preacher" Thomas Walker with the promise of Tamil lessons. ${ }^{53}$ Preena's arrival in 1901, changes forever Carmichael's work in this region. Swiftly accumulating more children and "daily becoming more burdened" Carmichael, forced to abandon her itinerating work, settles with her ever-growing band in Dohnavur. In this early period, despite immediate and dire physical needs, Carmichael continually reflects on the state of the souls of her young "family." Reflecting on Preena's first few months in her care she frankly states, "Pearl-eyes, otherwise the Elf, because it exactly describes her, was very good for the first few weeks, after which we began to know her. She is not a convert in any sense of the term. She is just a very wilful, truthful, exasperating and fascinating little Oriental." ${ }^{\prime 54}$

In a later work she would describe Preena's initial reaction to her new community: "when Pearl-eyes came to us, a much fêted child of seven, she regarded the life of the village church and congregation to which we then belonged with a grave and wondering scrutiny. 'Christianity is a dull religion' was her first comment." 55 After a few months, Preena, not having seen any pictures or representations of Jesus, receives a picture of her "new Lord." Carmichael describes her reaction: "'Who is this? Our Lord Jesus?' She gazed at it for a moment dismayed then burst into tears. 'I thought he was far more beautiful than that."'56 Quickly accumulating biblical knowledge Preena questions a visiting Bishop about his

\footnotetext{
50 Ibid.

51 George Marsden, "Fundamentalism as an American phenomenon, a comparison with English evangelicism," Church History: Studies in Christianity and Culture 46(2) (1977): 215-32, p. 220.

52 Work in this area of southern India is frequently described as itinerating with lady missionaries carrying out their work within ciricles of forty miles or more, often spending three to four weeks on end travelling in bullock carts superintending schools and Bible women. Irene H. Barnes, Behind the Pardah: The Story of C.E.Z.M.S Work in India, New York: Thomas Y. Crowell \& Company, 1897, p. 114.

53 Dyron Daughrity, “A dissonant mission: Stephen Neil, Amy Carmichael and missionary conflict in south India," International Review of Mission 97(384-385) (2008): 103-15, p. 106. Dohnavur, a town named after the pious and wealthy Prussian Count Dohna of Scholdin who made a generous gift to the area for a church building in 1824 lies just outside the border of the Princely state of Travancore in one of the last curves of the Western Ghats, in what was then known as the Madras Presidency.

54 Wilson-Carmichael, Things As They Are, p. 171.

55 Carmichael, Gold Cord, p. 323.

56 Ibid., p. 151.
} 
recent visit to the holy land asking, "Did you see Lot's Wife?" To his negative answer she offers the practical retort, "Oh, I suppose the salt has melted." 57 Relating a lesson about "how much Jesus had paid for us," to an incident in which Miss Carmichael paid off a temple lady who had accused Preena of stealing, Preena replies "Oh yes, I understand! I know how much you paid for me- fourpence halfpenny!"58 Disheartened on receiving a "negress" doll at Christmas, Preena implicates God in this wrong: "I thought God would have sent me a nicer doll!" ${ }^{59}$ Likewise airing her frustration over a failed exam she sobs: "I asked God so earnestly to let me pass, and I didn't pass! And I thought He had listened, but now I know He didn't listen at all." ${ }^{\prime 00}$ These anecdotes from Preena's first few years in the mission suggest what Miss Carmichael makes clear in her later work, "Pearl-eyes brought all her childish naughtiness to us direct, and sometimes they were serious. But we wrestled through together, again and again bringing her to Him who had redeemed her, and waiting for the full surrender which was so long delayed." ${ }^{61}$ While Carmichael never alludes exactly to how long Preena's surrender was delayed, this comment written more than thirty years after Preena's arrival betrays a sense of frustration persisting over time. Carmichael's expectations of an extreme form of lived Christianity are brought out in her description of true conversion, ${ }^{62}$ that "does not mean peace, but a sword ... [that] can cut to the quick." ${ }^{63}$

Eliza Kent usefully illustrates two ways of reading conversion experiences in the South Indian context. The first describes conversion as an immediate inner transformation, the second "a gradual, continual process of change that was both revealed in and aided by changes in external behavior." ${ }^{\prime 64}$ Kent notes the way "written representations of conversion reproduce existing class distinctions by stressing the interior dimension for elite converts and the exterior dimension for low-caste converts." ${ }^{65}$

In the gap between belief and the signs of belief manifested in practice lay the opportunity for massive intervention into the lives of Indian converts. The idea that the experience of conversion would be completed and perfected by changes in lifestyle led to the view that recent converts

\footnotetext{
57 Wilson-Carmichael, Things As They Are, p. 179.

58 Ibid., p. 168.

59 Ibid., p. 183.

60 Ibid., p. 184.

61 Carmichael, Gold Cord, pp. 151-52.

62 Many foreign missionaries did not live up to her expectations of a Christian life. At Dohnavur she did not allow furloughs to her missionaries, opposed marriage for her Indian girls, demanding of every worker a true "conviction of sin, a true repentance, honest confession and a change of life that lasted." See Carmichael, Gold Cord, p. 139.

63 Carmichael, Gold Cord, p. 304

64 Kent, Converting women, p. 6.

65 Ibid.
} 
needed a great deal of guidance before that initial, transformative experience could drive the changes necessary for new Christians' genuine conversion in behaviour, habit, custom, speech, and so forth. ${ }^{66}$

While not all of Carmichael's child converts were low-caste all were rendered diminutive by their age, and thus required the same intervention and guidance. Attempting to shape the behaviour of her children, Carmichael, a strict disciplinarian, matched punishment to crime.

A carelessly disobedient child would be sent to find a disobedient plant, one whose leaves ought to grow alternately or opposite or in whorls, and which disobeyed its law; a destructive one would be told to stick on the leaf it had plucked from pure wantonness - a deplorable habit too common here.... A quarrelsome child had a deer's horn tied round her neck, or, if very small, was put in a barrel out of which she could not climb. ${ }^{67}$

Known to put "quinine or ink on the rebellious tongue" or tie together the pig-tails of quarrelling girls, ${ }^{68}$ Carmichael sought to lay the foundations of her children's character "in truth" always in "the hope that they would be part of the crown of flowers that our Lord would wear one day." ${ }^{\prime 69}$ But as her accounts of Preena's "conversion" suggest this was a constant and prolonged battle, questioned, resisted and manipulated by children with their own agendas, values, and beliefs.

\section{Maturation}

Having begun her new life at the mission aged seven, Preena broke not only ties of religion, but of kinship and caste. Initially reluctant to surrender these, Preena on her first night away from the temple refused food from a low-caste Christian women stating: "Am I not a Vellala child? May you ask me to break my caste?"70 Preena, whose recently deceased father had been "a thoughtful and

\footnotetext{
66 Ibid., p. 7.

67 Carmichael, Gold Cord, p. 80.

68 Daughrity, Bishop Stephen Neil, pp. 107-08.

69 Carmichael, Gold Cord, pp. 67, 80.

70 Wilson-Carmichael, Things As They Are, p. 167. Here Preena invokes her caste position as a Vellala (variously called Valluvars), a Tamil sat-sudra (clean shudra) caste group. "The early protestant missionaries called them 'Shudras,' but the caste name Vellalar could denote any of a number of generally well to do and Sanskritised castes (Pillais, Mutaliyārs, etc.) who consisted the dominant, literate, property-owning class in the many Tamil speaking regions where the Brahman population was quite small." See Kent, Converting Women, p. 16. John Pickford a CMS missionary at Pannaivelei, to the south-east of Tinnevelly would, during the 1860s, describe the Vellala's insistence on caste superiority as irritating suggesting, "there is something particularly offensive to an Englishman's feelings in the ignorant pretensions of the Vellalas to superiority on account of their caste." Quoted in Antony Copley, Religions in Conflict: Ideology, Cultural Contact and
} 
scholarly Hindu landowner...famous as a reader and expounder of the religious poetry of his nation," ${ }^{\prime 11}$ here demands the respect to which her caste had accustomed her. Quickly having to readjust her expectations in the mixed-caste communally living band of mission workers, Carmichael records the persistence of Preena's caste attitudes. In the process of rejecting the aforementioned "negress doll" Preena did not hesitate to compare the "despised black beauty" to one of her peers remarking: "That black thing has a curly head just like Star's!"72 Here the caste prejudice is overwhelmingly familiar, yet as Preena and her peers come into contact with Europeans, racial questions emerge that are far removed from their everyday expectations. Shocked to discover that all the people in England are white, Preena and her peers inquire as to how they manage without servants. The answer that people in England are served by their fellow whites is met scoffingly "White people as servants! White servants!"73 This fact, irreconcilable with their lived experience of white people requires an explanation, one that is quickly provided by Preena. "At the beginning of the beginning of England, black people must have gone to be the white people's servants, and they gradually grew white. Yes that's it apparently; they faded."74 For Preena whose only experience of white people occurred within a colonial frame premised on the superiority of white over black, the conclusion that white servants in England were blacks that had eventually faded is a creative reconciliation of views that importantly preserves the truth of her experience both within the mission and in her lived experiences of colonisation.

Despite these caste tensions a familial air pervades Miss Carmichael's account, children addressing her, fellow workers and their peers in Tamil kinship terms. All children and workers address Carmichael as Amma (mother). Indian female workers are linguistically positioned as mother's younger sisters. Paired with characteristic quarrels and cheek the picture while overwhelmingly familiar is deeply entangled within a Christian cosmology that speaks to a broader conception of family. This is the conjugal family at its most broad: a community of women workers wedded to Christ, raising children who will succeed them in this service. In this departure from a strictly biological model of kinship, both devadasi communities and Carmichael's mission, share a fundamental disinclination towards conjugality. Rather than responding with tears of pity, I would like to seriously consider Rungi's question to Miss Carmichael: "Are

Conversion in Late Colonial India, Delhi: Oxford University Press, 1997, p. 153. During the 1880s the Vellalas increasingly challenged their position in the Hindu varna system, claiming that rather than sudras they should be considered as members of the Vaisya varna group. See Eugene F. Irschick, Dialogue and History: Constructing South India, 1795-1895, Berkeley: University of California Press, 1994, p. 197. See also Susan Bayly, Saints, Goddesses, and Kings: Muslims and Christians in South Indian Society 1700-1900, Cambridge: Cambridge University Press, 1989.

71 Carmichael, Gold Cord, p. 20.

72 Wilson-Carmichael, Things As They Are, p. 184

73 Ibid., p. 181.

74 Ibid., pp. 181-82. 
you not also servants of the Gods?"75 Carmichael, who strongly discouraged marriage for her girls, training them to work for the Lord, reproduces a model of "constructed kinship" superficially very similar to that of the devadasi system: ${ }^{76}$ one in which knowledge is transferred from older to younger female for the ultimate purpose of serving a non-physical male divinity. Yet while the ironies and paradoxes of these similarities may loom large in the post-colonial imagination, both the earnestness of Rungi's question, and the tears of pity shed by Miss Carmichael cannot fit in a picture that simply renders these reactions paradoxical. Similarly the tangible presence of God and other more malevolent super-natural forces alluded to both in Carmichael's and the children's use and manipulation of His authority too often escape acknowledgement in our secular age. Preena starting a quarrel with her "sister" Tangles invokes the following response from Tangles: "The devil has arrived in the middle of the afternoon to interrupt our unity and I won't let him!"77 This unlikely retort suggests a "family" environment imbued with far more than just paradox.

Preena who arrived at Dohnavur aged seven is first captured photographically in Carmichael's 1906 book Overweights of Joy (see Figure 22). ${ }^{78}$ Before Preena's eleventh birthday she shared the compound with seventeen other children, ${ }^{79}$ five years later we catch a glimpse of Preena's maturation in one of Penn's photographs taken in 1908 (see Figure 23). Here we see Preena aged fifteen, adorned with flowers for a "Coming-Day Feast." These coming days which mark the arrival of Children to Dohnavur are celebrated yearly. Carmichael describes a feast scene as follows. "The feasters sit on the floor in lines or circles. Before each is a large smooth plantain leaf. On this shinning [sic] satin plate is heaped rice and little piles of curried vegetables, or cakes, if it be a feast of cakes." ${ }^{\prime 80}$ Though some of Carmichael's books seem to suggest a uniform of blue for girls and red for boys, the majority of pictures capture the girls and women dressed in white. Eliza Kent suggests that this apparel, "drawing on widely recognized markers of virtuous widowhood in its ascetic and asexual mode," was adopted by South Indian Bible women in an attempt to "de-emphasize all traces of their sexual desirability or availability." ${ }^{\prime 1}$ This Indian style of food, dress and manner of eating was insisted upon by Miss Carmichael who elsewhere suggested that "to be foreign in dress, food or ways would have been to lock those doors, the only door to knowledge." ${ }^{22}$ Specifically referring to knowledge of the dedication

\footnotetext{
75 Carmichael, Gold Cord, p. 174.

76 Here I follow Hinchy's theorisation of "constructed kinship" (this volume Chapter 9).

77 Wilson-Carmichael, Things As They Are, p. 180.

78 The caption "a year later" is not clarified in the text providing little indication as to the exact date of this photo.

79 Eric Sharpe, "The legacy of Amy Carmichael," International Bulletin of Missionary Research 20(3) (1996):

121-25, p. 123.

80 Carmichael, Gold Cord, p. 326.

81 Kent, Converting Women, p. 155

82 Carmichael, Gold Cord, p. 23.
} 
of girls to temples, Carmichael adopted these external signs of indigeneity to facilitate her specific goals. For many of the children, the ability to preserve dietary, clothing and other customs may have meant something very different.

Miss Carmichael's books each tended to feature a young, cheeky, newly rescued child whose journey to religious submission, like Preena's, was made all the more delightful on account of their childish antics. Of the latter stages of Preena's maturation we see only glimpses such as the following account In Lotus Buds:

In this peaceful room Classes $\mathrm{B}, \mathrm{C}$, and D have taken the young teachers in hand-Rukma, Preena and Sanda. Of the three Rukma (Radiance) has the clearest ideas about discipline; Preena (the Elf) knows best how to coax; and Sanda, excellent Mouse that she is has the gift of patience. These three (who after all are only school girls, continuing their own education with their Prema Sittie) are attempting to instruct the babies on the lines of organised play; but the babies feel they have much to teach their teachers. ${ }^{83}$

Five years later, in a compound now home to more than one hundred and forty souls, ${ }^{84}$ Preena is listed with seven other girls described as "a band of keen and earnest workers." 85 Preena here is no longer instructing "babies on the lines of organised play" as "things have gradually grown more scholastic though not less cheerful in the K.G., or rather what is now a transition school where mature people of nine and ten and eleven have 'zaminations' and do occasionally take things seriously." 86 An image from Continuation of a Story (1914) captures Preena in her role as schoolteacher (see Figure 26). Around 1916, Preena aged roughly twenty-three pledges herself to a life of "celibacy and sacrificial ministry" in Carmichael's newly founded religious order, the Sisters of the Common Life. ${ }^{87}$

83 Wilson-Carmichael, Lotus Buds, p. 204.

84 Daughrity, Bishop Stephen Neil, p. 101.

85 Carmichael, The Continuation of a Story, p. 16.

86 Ibid., p. 27.

87 Carmichael, Gold Cord, p. 158. 


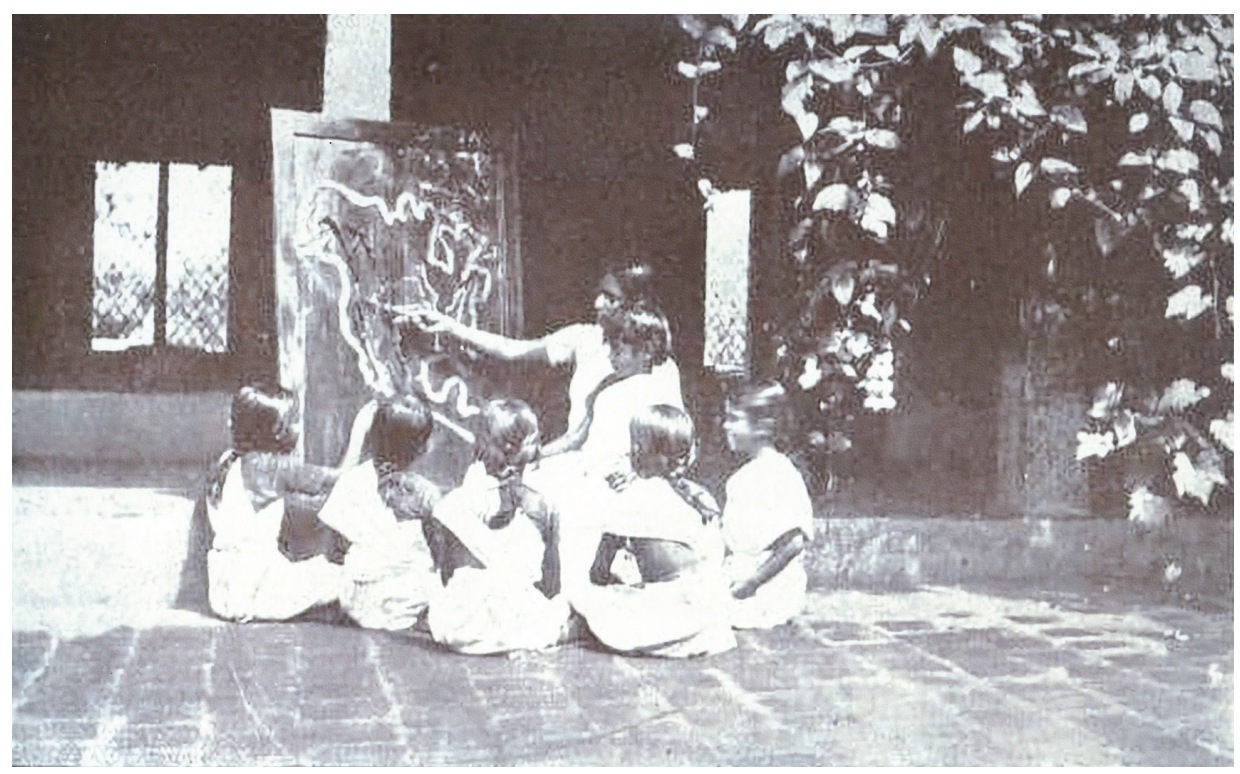

Figure 26. Preena and her class

Source: Unknown photographer, in Amy Carmichael, Continuation of a Story, London: Dohnavur Fellowship, 1914, p. 47.

To end Preena's story here, may seem like somewhat of disappointment, in terms of my stated goals of reconfiguring child and youth agency. I want to argue, that this is not the case. Rather, the disappointment lies in the absence of any record of Preena's own voice on this matter. This absence leaves the researcher with little option but to remain silent as to the configurations of agency and coercion in Preena's later choices to dedicate her life to the mission and the outcomes of these decisions. Conscious that my reconstruction of Preena's story cannot be separated from its place within Miss Carmichael's oeuvre, I do not suggest that Preena exerted agency in the exact tangible ways described by Miss Carmichael, but rather the possibility that she questioned, reasoned and engaged Miss Carmichael in similar and related ways. Reading and re-reading Miss Carmichael's description of Preena's rejection of the possibility of white servants I am continually struck with the simplicity and piercing nature of an insight that would put many post-colonial theorists to shame. Similarily Rungi's simple question pulses with the same intensity of insight. In choosing to define the space of these questions, comments, subtle manipulations and rejections as one of agency, I acknowledge it may well be one more easily occupied by younger children. The passage of time inevitably translates adorable childlike questions and behaviours into an unforgivable childishness incompatible 
with "proper" adult participation in the "real" world. ${ }^{88}$ Alternately without the charming innocence of early childhood the questions, resistance and manipulations of youth assume a more threatening guise at odds with the agenda of missionary publications. Karen Vallgårda whose attempts to read beyond the fragmentary records of one young boy's escape from a missionary boarding school in 1865 suggest that these disruptions to the missionary agenda, rather than necessarily infrequent, occupied very little official recorded space. That the absence of record does not amount to an absence of occurrence raises interesting questions for further investigations into the agency of those whose misdeeds are no longer forgivable as delightfully innocent. While Preena's nonrescue and delayed conversion can easily be seen to disrupt a simple rescue and conversion model, her maturation, education and employment in the mission speak to the complexities of an actual life, in which coercion and opportunity often subtly intertwine. Without diminishing the very real power differentials of age, race, class and religion that marginalised Preena both in life and in the domain of "history," this paper points to space in which children saw clearly, acted strongly, and reasoned wisely in situations where whiteness, authority and grace only met with locked doors and misinformation.

\section{Acknowledgements}

I would like to thank Jane Haggis from Flinders University for her thoughtful comments and encouragement on an initial draft of this chapter. I would also like to acknowledge the encouragement and support that was given to me as a first time presenter at the Paradoxes of Domesticity conference by all my fellow presenters but especially Margaret Jolly, Hyaeweol Choi, Kalpana Ram and Jessica Hinchy. I must extend a special thanks to Lucinda Shannon who read and listened to multiple drafts and garbled excited rants about this material always responding with thoughtful enthusiasm. And lastly to Carolyn Brewer who kindly and patiently answered all my silly questions and addressed my inexperience and careless errors.

88 Ashish Nandy, "Reconstructing childhood: a critique of the ideology of adulthood," in Traditions, Tyrannys and Utopias, Oxford: Oxford University Press, 1987, p. 65. 
This text taken from Divine Domesticities: Christian paradoxes in Asia and the Pacific, edited by Hyaeweol Choi and Margaret Jolly, published 2014 by ANU Press, The Australian National University, Canberra, Australia. 